\title{
Total SciComm - All out science communication
}

\author{
Hồ Mạnh Toàn \\ A.I. for Social Data Lab (AISDL) \\ toan@sshpa.com \\ Hồ Mạnh Tùng \\ Ritsumeikan Asia Pacific University \\ manhho18@apu.ac.jp
}

Hà Nội, 07-12-2018

\begin{abstract}
:
This essay seeks to introduce a philosophy of science communication: Total SciComm or all out science communication. The concept is inspired by the Dutch total football, in which, every player can play at any role. Similarly, in Total Scicomm, the scientific community employs every medium to communicate scientific ideas and engages all scientist in the process.
\end{abstract}

Keywords: philosophy of science communication; Total SciComm; all out science communication

Growing skepticism towards scientific findings makes capturing attention from the public an urgent and serious issue for the scientists. The attention will help raise the scientists' profiles as well as provide scientists a channel to communicate thorough scientific ideas. On YouTube and a new form of radio, podcast, the rise of the Intellectual dark web group is a prominent example of an effort for good and effective science communication (Weiss, 2018). However, mainstream science communication is still limited to conventional media like journalism or personal blog. In a world where "information strategy" is becoming more important (Arquilla \& Ronfedt, 2007; Mantello \& Douglas, 2018), science communication needs to employ every tool possible.

In 1974, Netherlands went to the FIFA World Cup final, and despite their loss, a new symbolic tactical theory emerged from their style: "Total Football". The theory is simple: every player on the field can play in any role (Wong, 2018). Inspired by Total 
Football, we would like to propose a method to do science communication calls: Total SciCom-Employing every form of the media to communicate sound scientific ideas and engaging all scientists in the process. Here are some examples:

Scientific novel: Human beings are a storytelling species, and storytelling is a powerful tool for scientists. Indeed, scientific research is often dry and technical, but significant findings can be translated into a narrative. For instance, Amanda C. Niehaus-a biologist-has written several novels and short stories based on her research. According to her own experience, unlike the certainty of research, writing fiction let her explores new possibilities and comes up with new ideas (Niehaus, 2018).

Scientific film and video: On YouTube, crash course videos or lecture videos have received a million views. They are usually short but have a strong visual animation to support the explanation. A film, as a more established art form, can be suffered from the artistic expression of the filmmaker. Nonetheless, the ability to visualize a scientific concept is their strength. Classic science fictions such as Blade Runner (1982) or 2001: A Space Odyssey (1968) utilize not only scientific ideas but also philosophical discussions. Nowadays, scientific journals have accepted video abstracts, providing another useful way to communicate the research.

Scientific game: the Game market is forecasted to reach US $\$ 137.9$ billion (Sinclair, 2018). The interactive gaming experience has become an important part of our popular culture. In the scientific community, scientists are testing board games or indie games to teach children scientific concepts (Kwok, 2017). Gamers even helped to find a solution for AIDS puzzle through a science puzzles game (Peckham, 2011). Not only the scientific concept, but gaming experience can also introduce the life and experiences of a scientist too. Thus, it is possible that a homemaker can learn the process of peer review through a mobile phone game calls The Peer Reviewer.

Scientific art: Artists have communicated abstract ideas for generations. However, as discussed above, the artistic expression sometimes stray too far away from the scientific truth. It does not mean that art is unable to utilize both. From September 2018 to January 2019, Science Gallery London introduced an art exhibition exploring the concept of addiction (Johnson, 2018). Scientists and artists are both searching for aesthetic, and there have been great artists are scientists too. 


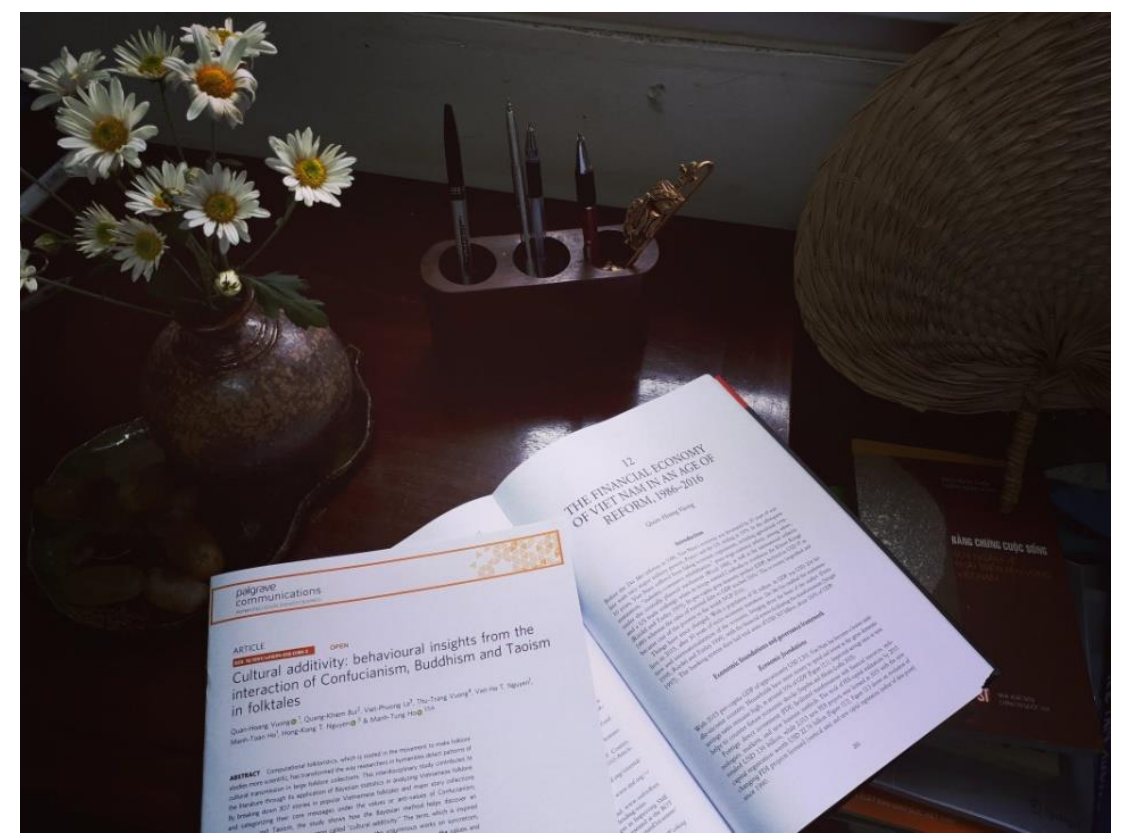

MIT Physicist Max Tegmark has argued the lack of active participation from the scientific community in communicating their ideas is dangerous for the sustainability of society (Tegmark, 2014). Moreover, lacking sound scientific communication together with the lack of transparency is a major reason why the public lacks a healthy perspective on the cost of doing science (Vuong, 2017; Vuong et al., 2018a).

Of course, similar to how a football coach with the total football philosophy must adapt to the specific circumstances of each match and innovate to maximize the winning chance, the scientific community in different countries must also adapt and innovate their Total SciComm tactics to their conditions. As new scientific ideas are always challenging, and deep-rooted cultural factors can influence vastly how the general public is adding these ideas to their world-view (Vuong et al., 2018b).

\section{References:}

Arquilla, J., \& Ronfeldt, D. F. (2002). Netwar revisited: the fight for the future continues. Low Intensity Conflict \& Law Enforcement, 11(2-3), 178-189. Doi: 10.1080/0966284042000279984

Kwok, R. (2017). Enterprise: Game on. Nature, 547, 369-371, doi:10.1038/nj7663369a.

Mantello, P., \& Douglas, P. (2018). Breaking point: Mapping the politics of extreme otherness in right-wing media of Brexit and the Refugee Crisis. In S., Rotella 
(Eds), The Challenges of Migration in North America and Europe (pp.65-87). New York, ST: Forum Italicum Publishing.

Niehaus, A. C. (2018). Write fiction to discover something new in your research. Nature, 557, 269, DOI: 10.1038/d41586-018-05089-x.

Peckham, M. (2011). Foldit gamers solve AIDS puzzle that baffled scientists for a decade. Time. Retrieved from http://techland.time.com/2011/09/19/folditgamers-solve-aids-puzzle-that-baffled-scientists-for-decade/ (Dec 12 2018).

Sinclair, B. (2018). Global games market to hit $\$ 137.9$ billion this year - Newzoo. Gameindustry.biz. Retrieved from https://www.gamesindustry.biz/articles/2018-04-30-global-games-marketto-hit-usd137-9-billion-this-year-newzoo (Dec 12 2018).

Tegmark, M. (2014). Our mathematical universe: My quest for the ultimate nature of reality. New York, Random House.

Vuong, Q. H. (2018). The (ir)rational consideration of the cost of science in transition economies. Nature Human Behaviour, 2(1), 5, DOI: 10.1038/s41562-0170281-4.

Vuong, Q. H., Bui, Q. K., La, V. P., Vuong, T. T., Nguyen, V. H., Ho, M. T., Nguyen, T. H. K. \& Ho, M. T. (2018b). Cultural additivity: Behavioural insights from the interaction of Confucianism, Buddhism, and Taoism in folktales. Palgrave Communications, 4, 143, DOI:10.1057/s41599-018-0189-2.

Vuong, Q. H., La, V. P., Vuong, T. T., Ho, M. T., Nguyen, H. K. T., Nguyen, V. H., Pham, H. H. \& Ho, M. T. (2018a). An open database of productivity in Vietnam's social sciences and humanities for public use.Scientific Data, 5, 180188, DOI: 10.1038/sdata.2018.188.

Weiss, B. (2018, May 8). Meet the renegades of the Intellectual Dark Web. New York Times.

Retrieved

from:

https://www.nytimes.com/2018/05/08/opinion/intellectual-dark-web.html (Dec 12 2018).

Wong, B. (2018). The mixer. Soccer and society, 19(4), 630-632, DOI: 10.1080/14660970.2018.1447317. 